\title{
Incidental Splenic Injury and Splenectomy. An Overview Based on Available Evidence
}

\author{
Lesión Esplénica Incidental y Esplenectomía. Una Visión General Basada en la Evidencia disponible
}

\author{
Carlos Manterola**** \& Tamara Otzen**
}

MANTEROLA, C. \& OTZEN, T. Incidental splenic injury and splenectomy. An overview based on available evidence. Int. J. Morphol., 34(4):1553-1560, 2016.

SUMMARY: Splenectomy indications are hematologic disease, traumatic damage and iatrogenic injury. The aim of this study was to present an evidence-based overview of some clinical aspects of interest related with iatrogenic splenic injury and subsequent splenectomy. An overview of the available evidence was conducted. Articles that evaluated clinical aspects of interest related with iatrogenic splenic injury and subsequent splenectomy, without language limits, publication date and designs. BVS, PubMed, SciELO and TRIP databases were reviewed. Evaluated variables were: Frequency and etiology of surgical spleen injuries, treatment options, frequency of splenectomy, associated postoperative morbidity (POM) and mortality, recommendation for splenectomy. Classification of the available evidence was made using the classification proposed by Oxford Centre of Evidence-based Medicine. 1144 records were obtained. 1109 were discarded for not meeting eligibility criteria, or were not relevant for the purpose of this research. Finally, the study consisted of 35 articles, 3 of evidence level type 3a, 31 of evidence level type 4 and 1 of evidence level type 5. Splenectomy is a complication of common abdominal procedures, prevalence and incidence of iatrogenic splenic injury is underestimated because of lack of information, there is evidence of risk factors of surgical spleen injuries, the etiology of surgical spleen injuries are bariatric, esophagogastric, antireflux, colorectal, abdominal vascular and urological procedures. POM in patients undergoing splenectomy is more frequent in emergency splenectomy secondary to trauma. There was no significant risk reduction of infectious complications after implementation of routine vaccination. Available evidence is based on few and heterogeneous articles, which make a meaningful conclusions difficult. Studies with better evidence levels, methodological quality and population size are needed for conclusions and recommendations.

KEY WORDS: "Splenectomy"[Mesh]; "Digestive System Surgical Procedures"[Mesh]; Gastrointestinal Surgical Procedures; antireflux surgery; postoperative morbidity.

\section{INTRODUCTION}

The spleen is a lymphoid organ, highlighting among its functions lymphopoiesis, erythropoiesis, hemolysis and immune role, being part of the lymphoid system (Hamouda, 2009). Located in the left hypochondrium, immediately below the diaphragm, above the left kidney and splenic flexure of the colon, and behind the fundus and gastric body (Fig. 1) (Moore \& Daley, 2005). Their intimate anatomical relationships associated with anatomical variants, allow the possibility of suffering damages during surgical procedures on some of these organs, and on others somewhat more distant such as the duodenum and gallbladder. Faced with such situations, often need splenectomy performed, to cease the bleeding secondary to splenic injury (Fig. 2).

There is evidence to support the fact that total splenectomy does not cause deleterious effects, especially in adults, because the functions of the spleen are assumed by other reticuloendothelial organs (Traub et al, 1987). Thus there are tissues and organs that produce more antibodies; the bone marrow as the primary hematopoietic organ is an immune regulatory organ capable of fine tuning immunity and may be a potential therapeutic target for immunotherapy and immune vaccination (Zhao et al., 2012), produces $\mathrm{T}$ and B cells (Nagasawa, 2006; Abo et al., 2012; Calvi \& Link, 2014), and red blood cells (Calvi \& Link, 2014). On the other hand the liver, the thymus and the hypothalamopituitary-adrenal axis kill more bacteria than the spleen itself. That is how most bacteria that enter the bloodstream are taken up and eliminated within the liver, elimination that depends on the complex interaction of Kupffer cells and bactericidal neutrophils that immigrate rapidly to the liver in response to infection (Gregory \& Wing, 2002; Holub et

\footnotetext{
* Department of Surgery and Center of Excellence in Morphological and Surgical Studies (CEMyQ), Universidad de La Frontera, Chile.

** Center for Biomedical Research, Universidad Autónoma, Chile.
} 


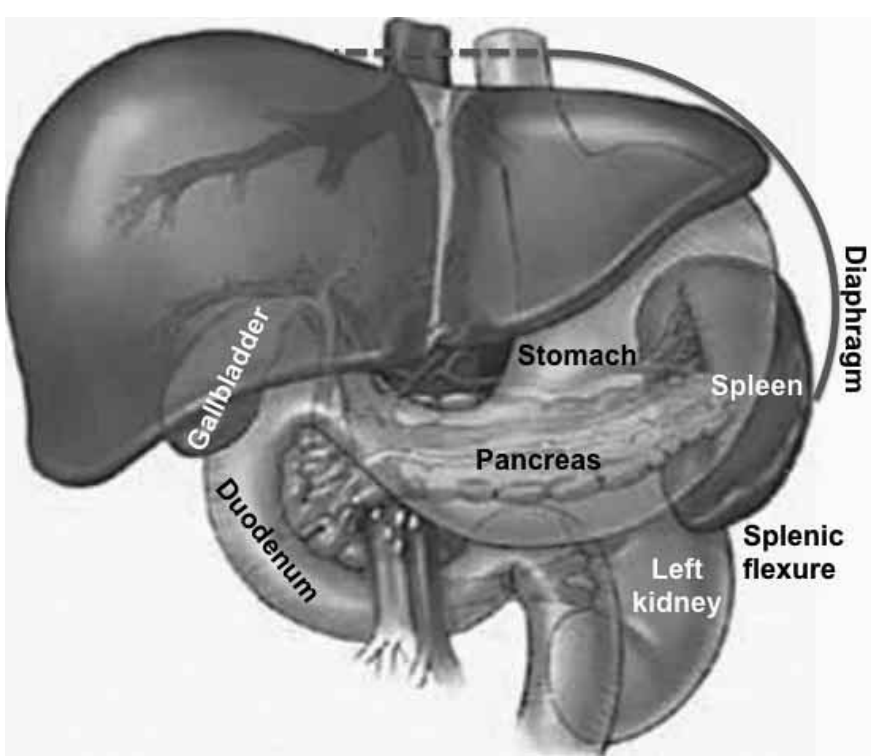

Fig. 1. Anatomical relationships of the spleen. The intimate proximity to the stomach, the tail of the pancreas, and the left kidney is appreciated.
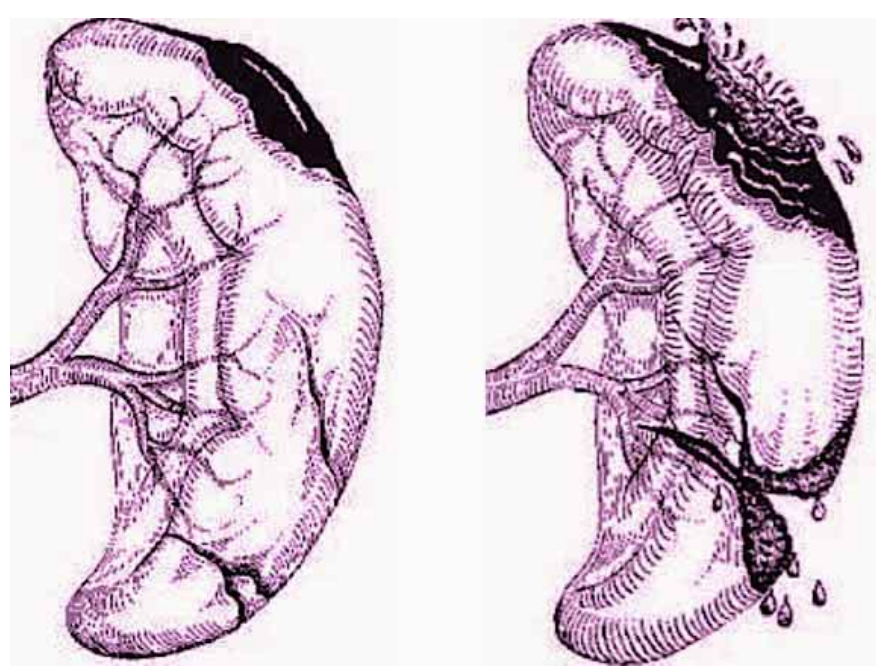

Fig. 2. Images of splenic lesions. The solution of continuity by the splenic capsule lesion is appreciated.

al., 2009). The thymus provides a niche for the successful development of T cells and B-1 cells (Shah \& Zúniga-Pflücker, 2014; Abo et al., 2012). On the other hand, the hypothalamicpituitary-adrenal axis modulates the inflammatory response during sepsis. Macrophage migration inhibitory factor, which counteracts the anti-inflammatory activity of glucocorticoid, is one of the mediators of the development of inflammation (Miyauchi et al., 2009; Kanczkowski et al., 2015); adrenal gland volume was found to be nearly double in sepsis compared with control patients. The absence of adrenal gland enlargement during septic shock predicts mortality (Nougaret et al., 2010). Further, pituitary gland is essential for homeostasis during an infectious episode and that GH plays an important role in host resistance by augmenting the ability of macrophages (Edwards et al., 1991; Edwards et al., 1992).

Iatrogenic injury or incidental intraoperative spleen damage is a very complex situation, because spleen lacerations, wounds and fractures may produce acute and important bleeding which determine secondary anemia and even hypovolemic shock with cardiac arrest. So, abdominal indications: hematologic, traumatic and iatrogenic injury, all with different POM and mortality in the immediate postoperative period, especially regarding late postoperative aftermath (especially infectious) (Gómez Alonso et al., 2001).

Complications of splenectomy derive from the nature of the organ, its immunological and hematological functions, as well as its structure and topographical situation (Wybran, 1983). Of particular interest for surgeons is POM that occurs from closed trauma and from accidental injury during surgery, as they are associated with an increased risk of complications (Liu et al., 1994). However, one of the major problems to being able to dimension this problem is that there are no articles in which only the results of accidental intraoperative splenectomy are reported since the articles are contaminated with elective and emergency splenectomies, as well as trauma and accidental injury during surgery.

The major interest for the surgeon is the complications that occur in patients with accidental injury during surgery, because it is one of the most frequent indication of splenectomy (up to $40.0 \%$ ) (Gómez Alonso et al., 2001), but the prevalence and incidence of iatrogenic splenic injury is underestimated because of lack of information.

The aim of this study was to present an evidencebased overview of some clinical aspects of interest related with iatrogenic splenic injury and subsequent splenectomy.

\section{MATERIAL AND METHOD}

Study design: Overview of the available evidence.

Center: Department of Surgery and the Center for Excellence in Morphological and Surgical Studies (CEMyQ), Universidad de La Frontera.

Population: Articles that evaluated clinical aspects of interest related with iatrogenic splenic Injury and 
subsequent splenectomy, without limits of language, publication date and designs.

Search strategy: The search was conducted according to PICoR components: population of interest ( $\mathrm{p}$ ), intervention to be evaluated (i), the comparator for the intervention being studied $(\mathrm{Co})$, and the variable result measured from the intervention (R). Using this strategy, studies were sought regarding subjects with indication of abdominal surgery or digestive procedures (p), those where splenectomy was performed (I), and whose response variables would be: POM, complications, mortality, etc. (R). To do this, the following databases were reviewed: BVS, PubMed, SciELO and TRIP database. Sensitive searches were conducted using MeSH terms, free words and Boolean connectors AND and OR, using strategies adapted for each database.

Variables: The variables evaluated were: frequency and etiology of surgical spleen injuries (type of procedures and surgeries), treatment options (conservative and splenectomy), frequency of incidental splenectomy, associated POM (percentages and type of complications), associated mortality, recommendation for splenectomy in cases of surgical spleen injuries.

Synthesis and evaluation of the evidence: Classification of the available evidence was made using the classification proposed by Oxford Centre for Evidence-based Medicine for prognostic, prevention and therapy scenarios (CEBM, 2009).

Statistics: The selected data were collected in a Windows Excel spreadsheet. Then, the information from each article was analyzed, extracting the data of interest.

Ethical Principles: During the analysis of the selected articles, the authors and centers where the studies originated were masked to further reduce selection and analysis bias.

\section{RESULTS}

Of all revised databases, 1144 records were obtained (BVS=318, PubMed=739, SciELO=40 and TRIP database $=47$ ). One hundred forty-nine were discarded by duplication between databases. Eight hundred sixty seven were discarded by exclusion criteria in the abstracts, or for not being relevant to the objective of the investigation. Thirty-nine articles in extensive were discarded for failing to meet the eligibility criteria. Finally, the population in study consisted of 35 articles, 3 of evidence level type 3 a (Renzulli et al., 2009; He et al., 2014; Piccolo et al., 2014), 32 of evidence level type 4 (Bagrodia et al., 2014; Barmparas et al., 2015; Bracale et al., 2013; Cassar \& Munro, 2009; Coon, 1990; Chung et al., 2011; Davies et al., 2014; Eaton et al., 2000; Eber et al., 1999; Edgren et al., 2014; Flum et al., 2001; Geraci et al., 2014; Gómez Alonso et al., 2001; Ha \& Minchin, 2009; Harbrecht et al., 2008; Holubar et al., 2009; Kamath et al., 2009; Malek et al., 2007; Masoomi et al., 2012; McIntyre et al., 2005; Merchea et al., 2012; Nikolaev et al., 1990; Ong et al., 1991; Paredes et al., 2013; Rogers et al., 1980; Singla, et al., 2012; Tan et al., 2011; Urschel, 1993; Wang et al., 2011; Yong et al., 2010; Zhao et al., 2012) and 1 of evidence level type 5 (American Society for Metabolic \& Bariatric Surgery, 2012).

There is evidence proposing as risk factors of surgical spleen injuries, previous abdominal surgery, elderly and obese patients (Evidence level type 4) (Gómez Alonso et al., 2001; Cassar \& Munro, 2009). There is also evidence suggesting the indication for splenectomy as a risk factor, with standardized incidence ratios varying from 3.4 (95\% CI, 3.0-3.8) for trauma patients to 18 (95\% CI, 16-19) for patients with hematologic malignancies (Evidence level type 4) (Edgren et al., 2014). Other studies suggest something similar regarding pediatrics and patients with hematologic diseases (Evidence level type 4) (Gómez Alonso et al., 2001).

In relation to the frequency of surgical spleen injuries, it was found evidence suggesting that: $9.7 \%$ of patients required control of continued bleeding from unrecognized iatrogenic splenic trauma (Evidence level type 4) (Coon, 1990). Splenectomy was performed in $2.3 \%$ of 86,411 patients that underwent antireflux surgery of a populationbased cohort study (Evidence level type 4) (Flum et al., 2001).

Regarding the etiology of surgical spleen injuries (type of procedures and surgeries), it was found evidencesuggesting prevalence of $0.5 \%$ in upper tract urological laparoscopic surgery, recognized intraoperative in $85.7 \%$ (Evidence level type 4) (Chung et al., 2011); left nephrectomy 4.0 to $14.5 \%$ (Evidence level type 4) (Cassar \& Munro, 2009; Coon, 1990; Tan et al., 2011); during elective left hemicolectomy in $0.24 \%$ to $8.0 \%$ (Evidence level type 4) (Coon, 1990; Malek et al., 2007; Holubar et al., 2009; Cassar \& Munro, 2009; Merchea 2012; Masoomi et al., 2012); during antireflux surgery in 2.0 to $20 \%$, depending on characteristics of patients (Evidence level type 4) (Coon, 1990;Urschel, 1993; Flum et al., 2001; Cassar \& Munro, 2009); during abdominal vascular surgery 21.0 to $60.0 \%$ (Evidence level type 4) (Eaton et al., 2000; Cassar \& Munro, 2009; Coon, 1990); in the course of surgery for gastric and duodenal ulcers injuries of the spleen were found 
in $1.4 \%$ of patients (Evidence level type 4) (Nikolaev et al., 1990); as a complication of upper gastrointestinal endoscopy, ERCP and colonoscopy (Evidence level type 3a and 4) (Piccolo et al., 2014; Ong et al., 1991; Kamath et al., 2009; Ha \& Minchin, 2009; Paredes et al., 2013); in the course of laparoscopic cholecystectomy (Evidence level type 4) (Bracale et al., 2013; Geraci et al., 2014); as a complication of bariatric surgery, were found in $0.21 \%$ of patients (Evidence level type 5) (American Society for Metabolic \& Bariatric Surgery, 2012).

Concerning treatment options for a spleen injury (conservative or splenectomy), we found evidence of 76.0 $\%$ to $84.8 \%$ of splenectomies vs. conservative procedures in patients with splenic injury during elective colectomy (Evidence level type 3a and 4) (Renzulli et al., 2009; Holubar et al., 2009; Merchea et al., 2012; Masoomi et al., 2012).

About the frequency of incidental splenectomy, we found evidence suggesting of $2 \%$ in patients underwent antireflux surgery (Evidence level type 4) (Urschel, 1993); incidental splenectomies were most commonly associated with operations on the esophagus/stomach (32.0\%) and colon (30.0\%) (Evidence level type 4) (Harbrecht et al., 2008).

On the topic of associated POM (percentages and type of complications), we found evidence suggesting that 30day major POM rate was $21.0 \%$ to $34.0 \%$ (Evidence level type 4) (Holubar et al., 2009; Davies et al., 2014). There is no evidence that POM could increase if the splenic injury is promptly recognized and managed by splenectomy (Evidence level type 4) (Coon, 1990). In patients undergoing antireflux surgery, perioperative complications included spleen laceration, splenectomy and transfusion among others, especially in older-aged patients (Evidence level type 4) (Gómez Alonso et al., 2001; Wang et al., 2011). The overall standardized incidence ratios for hospitalization for sepsis in a retrospective cohort study of all patients in the Swedish national inpatient register $(\mathrm{N}=20,132)$ was 5.7 [95\% CI 5.6-6.0] (Evidence level type 4) (Edgren et al., 2014). On the other hand, in a systematic review based on MEDLINE, EMBASE and Cochrane Library performed to evaluate and compare the clinical outcomes between spleen-preserving distal pancreatectomy and distal pancreatectomy with splenectomy, that included 11 non-randomized controlled studies ( $\mathrm{N}=897$ patients), spleen-preserving had a lower incidence of intra-abdominal abscesses $(\mathrm{OR}=0.48,95 \%$ $\mathrm{CI}=0.27,0.83$ ), but there were no differences respect to operative blood loss, requirement for blood transfusion, postoperative bleeding, wound infections and re-operation rates (Evidence level type 3a) (He et al., 2014). In a retrospective study of patients who were scheduled to receive laparoscopic surgery for distal pancreatic lesions spleen-preserving distal pancreatectomy and distal pancreatectomy with splenectomy were compared in terms of POM, and no significant differences were reported in complications and POM rates between the two groups (Evidence level type 4) (Zhao et al., 2012).

In a comparative study patients with splenectomy vs. patients with other abdominal surgery had $49 \%$ vs. $29 \%$ of POM respectively (OR 2.7 [95\% CI 1.3, 5.6]); but on a subgroup analysis, there were no differences between traumatic and elective splenectomy with regards to overall infectious complications ( $50 \%$ vs. $46 \%, \mathrm{p}=0.84$ ) (Evidence level type 4) (Barmparas et al., 2015). Surgical wound infection is up to $7.0 \%$. (Evidence level type 4) (Gómez Alonso et al., 2001).

With regard to associated mortality, we found evidence suggesting that: 30 -day mortality rate was 1.6 to $17.0 \%$ (Evidence level type 4) (Bagrodia et al., 2014; Davies et al., 2014; Holubar et al., 2009). On the other hand, in a historical population-based cohort study conducted in Denmark ( $\mathrm{N}=3812$ splenectomised patients), the adjusted relative risk for death, regardless of indication, was highly elevated compared to the general population (RR 33.6 [95 $\%$ CI $6.9,35.0$ ) but when compared to the matched indication cohort, short- and long-term mortality risk with splenectomy was not increased. So most of this risk seems to be due to the underlying splenectomy indication and not to splenectomy alone (Yong et al., 2010).

In relation to recommendation for splenectomy in cases of surgical spleen injuries, we found evidence suggesting there was no significant association between the surgical management of splenic injuries and short- or longterm outcomes. Splenic salvage is frequently unsuccessful so surgeons should not be reluctant to perform splenectomy when initial repair attempts fail (Evidence level type 4) (Holubar et al., 2009). There is also evidence about splenic injury not recognized intraoperatively presented with delayed hemorrhage, which determines the need to reoperation and splenectomy $14.3 \%$ (Evidence level type 4) (Chung et al., 2011); and $7 \%$ in patients with splenic injury during elective colectomy (Evidence level type 4) (Holubar et al., 2009; Merchea et al., 2012).

About the utility of vaccination in patients undergoing splenectomy, we found evidence in a regression analyses adjusting for age at splenectomy, follow-up time, sex, and calendar year of splenectomy, there were no significant risk decreases after implementation of routine vaccination, except in patients with malignant and non-malignant hematologic disease, therefore, the effectiveness of current vaccination practices warrants further evaluation (Evidence level type 
4) (Edgren et al., 2014). On the other hand, there are reports of an insufficient response to pneumococcal vaccination in patients with infections (Evidence level type 4) (Eber et al., 1999).

Relating to "incidental splenectomy", there is evidence that insinuates splenectomy as a complication of common abdominal procedures. It was verified that $20.0 \%$ to $40.0 \%$ of all splenectomies are performed for iatrogenic splenic injury (Evidence level type 4) (Coon, 1990; Gómez Alonso et al., 2001; Harbrecht et al., 2008; Cassar \& Munro, 2009), on the other hand splenic preservation is desirable and feasible, but this should not be at the expense of excessive blood loss (Evidence level type 4) (Cassar \& Munro, 2009).

\section{DISCUSSION}

POM and mortality rates of splenectomised patients are $21.0 \%$ and $8.6 \%$ respectively (Davies et al., 2014). Splenectomy performed in continuity with a major abdominal procedure designed to remove visceral cancer, and when carried out as an iatrogenic misfortune reports between 10$30 \%$ of all splenectomies. The frequency varies depending in the primary operation but incidental splenectomy is most always associated with surgical procedures carried out on organs in close proximity as the esophagus (for example antireflux surgery), stomach, and splenic flexure of the colon. Despite the relative frequency of iatrogenic splenectomy, its effect on POM and mortality remains controversial. For example, in a comparative study in patients that underwent antireflux surgery the group with Nissen fundoplication had $12.5 \%$ of significant POM in comparison with the group of Nissen fundoplication and splenectomy, which experienced to $36 \%(\mathrm{p}<0.1)$ (Evidence level type 4) (Rogers et al., 1980); in other study of 18-year follow-up period in 105 splenectomised patients no evidence of OPSI was verified (Evidence level type 4) (Davies et al., 2014). In a review of the American College of Surgeons National Surgical Quality Improvement Program, including 1344 splenectomised patients, it was verified that patients treated for malignant disease had a higher rate of overall complications (27.2\%) compared with patients treated for benign disease $(14.1 \%)$ ( < 0.001$)$ (Evidence level type 4) (Bagrodia et al., 2014).

On the other hand, in a retrospective descriptive population study all patients admitted with blunt splenic trauma were identified from a statewide trauma registry at the Harborview Injury Prevention Research Center in Seattle, to determine factors associated with failure of non-operative management of blunt splenic injuries. Of the 2243 patients in study, 610 (27\%) underwent immediate splenectomy, splenorrhaphy, or splenic embolization within 4 hours. Of the remaining 1633 who were admitted with planned nonoperative treatment, 252 patients (15\%) failed; founding that being older than 55 years and having an Injury Severity Score higher than 25 were significantly associated with failure, which increases the risk of postoperative mortality, because unrecognized splenic bleeding is a primary cause of preventable mortality (Evidence level type 4) (McIntyre et al., 2005).

There is also evidence that sustains through a metaregression analysis using a mixed generalized linear model, some risk factors associated with splenic injury during colonoscopy. These are: females ( $76.5 \%)$ and over 65 years of age. Seventy-three patients underwent surgery and $96 \%$ of these were treated with splenectomy (Evidence level type 4) (Singla, et al., 2012). In the same way, other studies determined age over 55 years old as the only significant and independent prognostic indicator of POM in a multivariate analysis (Davies et al., 2014). Another study in 1344 splenectomised patients permitted verified independent predictors of complications in this type of patients. These are: malignant disease (vs. benign) (OR 1.86; $95 \%$ CI, $1.23-$ 2.80); independent performance status (vs. dependent) (OR, 0.33 ; $95 \%$ CI, 0.07-1.52); and increasing albumin level (OR, $0.75 ; 95 \% \mathrm{CI}, 0.66-0.86)$; but increasing age (OR, 1.03; 95 $\% \mathrm{CI}, 1.00-1.06)$ is an independent predictor of mortality, so a patient older than 60 years with a low preoperative albumin level has a predicted probability for operative death as high as $10.0 \%$ (Evidence level type 4) (Bagrodia et al., 2014).

By way of conclusion, it can be mentioned that: There is evidence that, there are a number of organs and tissues that replace the function of the spleen. Also that insinuates splenectomy is a complication of common abdominal procedures. Data from greater number of splenectomies regarding operative outcomes to help guide decision-making are lacking. There are no articles in which only the results of accidental intraoperative splenectomy are reported. The prevalence and incidence of iatrogenic splenic injury is underestimated because of lack of information. Nevertheless it represents one of the most frequent indications of splenectomy. There is evidence of risk factors of surgical spleen injuries, such as elderly and obese patients, hematologic diseases The etiology of surgical spleen injuries are: upper tract urological laparoscopic surgery, left nephrectomy, elective left hemicolectomy, antireflux surgery, abdominal vascular surgery, surgery for gastric and duodenal ulcers, bariatric surgery, etc. Evidence suggests 30-day major POM in patients undergoing splenectomy, more frequent in emergency splenectomy secondary to trauma. Spleenpreserving had a lower incidence of intra-abdominal abscesses with reference to splenectomy, but there were no 
differences with respect to operative blood loss, requirement for blood transfusion, post-operative bleeding, wound infections and re-operation rates. Splenic salvage is frequently unsuccessful so surgeons should not be reluctant to perform splenectomy when initial repair attempts fail. Splenic injury not recognized intraoperatively presented with delayed hemorrhage, determines the need for reoperation and splenectomy. There were no significant risk decreases of infectious complications after implementation of routine vaccination, except in patients with malignant hematologic disease. Furthermore, articles found are few and of low evidence level, making meaningful conclusions difficult. Studies with a better level of evidence and methodological quality are needed to make conclusions and recommendations.

MANTEROLA, C. \& OTZEN, T. Lesión esplénica incidental y esplenectomía. Una visión general basada en evidencia disponible. Int. J. Morphol, 34(4):1553-1560, 2016.

RESUMEN: Las indicaciones de esplenectomía son enfermedades hematológicas, daño por trauma y por lesiones iatrogénicas. El objetivo de este estudio es presentar una visión general basada en la evidencia actualmente disponible, respecto de algunos aspectos clínicos de interés relacionados con la lesión esplénica iatrogénica y posterior esplenectomía. Revisión global de la evidencia disponible. Se incluyeron artículos que evaluaron aspectos clínicos de interés relacionados con lesión esplénica iatrogénica y posterior esplenectomía; sin límites de lenguaje, fecha de publicación y diseño. Se revisaron las bases de datos BVS, PubMed, SciELO y Trip Database. Las variables evaluadas fueron: frecuencia y etiología de las lesiones, opciones de tratamiento, frecuencia de esplenectomía, morbimortalidad postoperatoria, recomendación de esplenectomía. La clasificación de la evidencia se realizó con la propuesta del Centro de Medicina Basada en la Evidencia de Oxford. Se obtuvieron 1144 registros. 1109 fueron descartados por no cumplir criterios de elegibilidad, o ser no relevantes para el objetivo de la investigación. La población en estudio quedó compuesta por 35 artículos, 3 de nivel de evidencia 3a, 31 de nivel de evidencia 4 y 1 de nivel de evidencia 5 . La esplenectomía es una complicación propia de la cirugía abdominal. La prevalencia e incidencia de lesión esplénica iatrogénica es subestimada por falta de información. Hay evidencia de factores de riesgo de lesiones del bazo. La etiología de estas es: procedimientos bariátricos, esófago-gástricos, colorrectales, vasculares abdominales y urológicos. La morbilidad es más frecuente en esplenectomía de emergencia secundaria a trauma. No se ha registrado disminución significativa del riesgo de complicaciones infecciosas con la vacunación rutinaria. La evidencia disponible se basa en pocos artículos y heterogéneos, lo que impide sacar conclusiones. Se necesitan estudios de mejor nivel de evidencia, calidad metodológica y tamaño de muestra para obtener conclusiones válidas y recomendaciones adecuadas.

PALABRAS CLAVE: Esplenectomía; Cirugía gastrointestinal; Cirugía del aparato digestivo; Cirugía antireflujo.

1558

\section{REFERENCES}

Abo, T.; Tomiyama, C.; Watanabe, H. Biology of autoreactive extrathymic T cells and B-1 cells of the innate immune system. Immunol. Res., 52(3):224-30, 2012.

American Society for Metabolic \& Bariatric Surgery. Bariatric surgery: American society for metabolic \& bariatric surgery guidelines. Available at: http://lapsurgery.com/ B A R I A T R I C \% 200 S U R G E R Y / ASBS.htm\#PERIOPERATIVE\%20COMPLICATIONS. Consulted January 21, 2016.

Bagrodia, N.; Button, A.M.; Spanheimer, P.M.; Belding-Schmitt, M. E.; Rosenstein, L. J.; Mezhir, J. J. Morbidity and mortality following elective splenectomy for benign and malignanthematologic conditions: analysis of the American College of Surgeons National Surgical Quality Improvement Program data. JAMA Surg., 149(10):1022-9, 2014.

Barmparas, G.; Lamb, A.W.; Lee, D.; Nguyen, B.; Eng. J.; Bloom, M.B.; Ley, E.J. Postoperative infection risk after splenectomy: A prospective cohort study. Int. J. Surg., 17:10-4, 2015.

Bracale, U.; Merola, G.; Lazzara, F.; Spera, E.; Pignata, G. Spleen rupture: an unusual postoperative complication after laparoscopic cholecystectomy. Ann. Ital. Chir., 28:84, 2013.

Calvi, L.M. \& Link, D.C. Cellular complexity of the bone marrow hematopoietic stem cell niche. Calcif. Tissue Int., 94(1):11224, 2014.

Cassar, K.; Munro, A. Iatrogenic splenic injury. J. R. Coll. Surg. Edinb., 47(6):731-41, 2002.

CEBM. Centre for Evidence-based Medicine. Oxford Centre for Evidence-based Medicine - Levels of Evidence (March 2009). Available at: http://www.cebm.net/oxford-centre-evidencebased-medicine-levels-evidence-march-2009/. Consulted January 2, 2016.

Chung, B.I.; Desai, M.M.; Gill, I.S. Management of intraoperative splenic injury during laparoscopic urological surgery. BJU Int., 108(4):572-6, 2011.

Coignard-Biehler, H.; Lanternier, F.; de Montalembert, M.; Mahlaoui, N.; Suarez, F.; Lecuit, M.; Lortholary, O. Infections in splenectomized patient. Rev Prat., 58(20):2209-14, 2008.

Coon, W.W. Iatrogenic splenic injury. Am. J. Surg., 159(6):585-8, 1990.

Davies, I.L.; Cho, J.; Lewis, M.H. Splenectomy results from an 18-year single centre experience. Ann. R. Coll. Surg. Engl., 96(2):147-50, 2014.

Derogar, M.; Sadr-Azodi, O.; Lagergren, P.; Lagergren, J. Splenic 
injury during resection for esophageal cancer: risk factors and consequences. Ann. Surg., 261(1):111-6, 2015.

Eaton, M.A.; Valentine, J.; Jackson, M.R.; Modrall, G.; Clagett, P. Incidental splenic injury during abdominal vascular surgery: a case-controlled analysis. J. Am. Coll. Surg., 190(1):58-64, 2000 .

Eber, S.W.; Langendörfer, C.M.; Ditzig, M.; Reinhardt, D.; Stöhr, G.; Soldan, W. et al. Frequency of very late fatal sepsis after splenectomy for hereditary spherocytosis: impact of insufficient antibody response to pneumococcal infection. Ann. Hematol., 78(11):524-8, 1999.

Edgren, G.; Almqvist, R.; Hartman, M.; Utter, G.H. Splenectomy and the risk of sepsis: a population-based cohort study. Ann. Surg., 260(6):1081-7, 2014.

Edwards, C.K. 3rd.; Yunger, L.M.; Lorence, R.M.; Dantzer, R.; Kelley, K.W. The pituitary gland is required for protection against lethal effects of Salmonella typhimurium. Proc. Natl. Acad. Sci. U S A., 88(6):2274-7, 1991.

Edwards, C.K. 3rd.; Arkins, S.; Yunger, L.M.; Blum, A.; Dantzer, R.; Kelley, K.W. The macrophage-activating properties of growth hormone. Cell. Mol. Neurobiol., 12(5):499-510, 1992.

Flum, D.R.; Koepsell, T.; Heagerty, P.; Pellegrini, C.A. The nationwide frequency of major adverse outcomes in antireflux surgery and the role of surgeon experience, 1992-1997. J. Am. Coll. Surg., 195(5):611-8, 2002.

Geraci, G.; Picciurro, A.; Attard, A.; Modica, G.; Cajozzo, M.; Sciumè, C. A case of splenic rupture: a rare event after laparoscopic cholecystectomy. BMC Surg., 14:106, 2014.

Gómez Alonso, A.; Santos Benito, F.F.; González Fernández, L.; Gómez Gómez, J.M.; Bellido Luquea, A.; González Fraile, M.I.; García Plaza, A. Complications in splenectomy. An analysis of our case history. Cir. Esp., 69(3):224-30, 2001.

Ha, J.F. \& Minchin, D. Splenic injury in colonoscopy: a review. Int. J. Surg., 7(5):424-7, 2009.

Hamouda, A. Interactive Thorax and Abdomen. Interactive thorax and abdomen - a stunning and detailed image library and reference tool for an in-depth view of the thorax and abdomen. Interactive thorax and abdomen DVD-ROM - 2009 release. Primal Pictures Ltd. London, United Kingdom.

Harbrecht, B.G.; Franklin, G.A.; Miller, F.B.; Richardson, J.D. Is splenectomy after trauma an endangered species? Am Surg., 74(5):410-2, 2008.

He, Z.; Qian, D.; Hua, J.; Gong, J.; Lin, S.; Song, Z. Clinical comparison of distal pancreatectomy with or without splenectomy: a meta-analysis. PLoS One, 9(3):e91593, 2014.
Holub, M.; Cheng, C.W.; Mott, S.; Wintermeyer, P.; van Rooijen, N.; Gregory, S.H. Neutrophils sequestered in the liver suppress the proinflammatory response of Kupffer cells to systemic bacterial infection. J. Immunol., 183(5):3309-16, 2009.

Holubar, S.D.; Wang, J.K.; Wolff, B.G.; Nagorney, D.M.; Dozois, E.J.; Cima, R.R. et al. Splenic salvage after intraoperative splenic injury during colectomy. Arch Surg., 144(11):1040-5, 2009.

Kamath, A.S.; Iqbal, C.W.; Sarr, M.G.; Cullinane, D.C.; Zietlow, S.P.; Farley, D.R.; Sawyer, M.D. Colonoscopic splenic injuries: incidence and management. J. Gastrointest. Surg., 13(12):2136-40, 2009.

Kanczkowski, W.; Sue, M.; Zacharowski, K.; Reincke, M.; Bornstein, S.R. The role of adrenal gland microenvironment in the HPA axis function and dysfunction during sepsis. Mol. Cell. Endocrinol., 408:241-8, 2015.

Liu, P.P.; Chou, F.F.; Sheen-Chen, S.M.; Chen, Y.S.; Chen, M.J.; Chen, F.C. Complications of splenectomy for splenic injury. Chang Keng I Hsuch., 17:125-30, 1994.

Malek, M.M.; Greenstein, A.J.; Chin, E.H.; Nguyen, S.Q.; Sandler, A.L.; Wong, R.K. et al. Comparison of iatrogenic splenectomy during open and laparoscopic colon resection. Surg. Laparosc. Endosc. Percutan. Tech., 17(5):385-7, 2007.

Masoomi, H.; Carmichael, J.C.; Mills, S.; Ketana, N.; Dolich, M.O.; Stamos, M.J. Predictive factors of splenic injury in colorectal surgery: data from the Nationwide Inpatient Sample, 20062008. Arch. Surg., 147(4):324-9, 2012.

McIntyre, L.K.; Schiff, M.; Jurkovich, G.J. Failure of nonoperative management of splenic injuries: causes and consequences. Arch. Surg., 140(6):563-8, 2005.

Merchea A.; Dozois, E.J.; Wang, J.K.; Larson, D.W. Anatomic mechanisms for splenic injury during colorectal surgery. Clin. Anat., 25(2):212-7, 2012.

Miyauchi, T.; Tsuruta, R.; Fujita, M.; Kaneko, T.; Kasaoka, S.; Maekawa, T. Serum macrophage migration inhibitory factor reflects adrenal function in the hypothalamo-pituitary-adrenal axis of septic patients: an observational study. BMC Infect. Dis., 9:209, 2009.

Moore, K.L. \& Daley, F. Clinically Oriented Anatomy Paperback. Lippincott Williams and Wilkins; 5th Revised edition (1 May 2005).

Nagasawa, T. Microenvironmental niches in the bone marrow required for B-cell development. Nat. Rev. Immunol., 6(2):107$16,2006$.

Nikolaev, N.O.; Grishin, S.G.; Startsev, A.I.; Chekmazov, I.A. Intraoperative injuries of the spleen. Vestn. Khir. Im. I I Grek., 145(10):94-6, 1990 
Nougaret, S.; Jung, B.; Aufort, S.; Chanques, G.; Jaber, S.; Gallix, B. Adrenal gland volume measurement in septic shock and control patients: a pilot study. Eur. Radiol., 20(10):2348-57, 2010 .

Ong, E.; Bohmler, U.; Wurbs, D. Splenic injury as a complication of endoscopy, two case report and literature review. Endoscopy, 23(5):302-4, 1991.

Paredes, A.H.; Williams, A.M.; Vertrees, A.E.; Womeldorph, C. Splenic laceration following ERCP. Endoscopy, 45 Suppl 2, UCTN:E221-2, 2013.

Piccolo, G.; Di Vita, M.; Cavallaro, A.; Zanghì, A.; Lo Menzo, E.; Cardì, F.; Cappellani, A. Presentation and management of splenic injury after colonoscopy: a systematic review. Surg. Laparosc. Endosc. Percutan. Tech., 24(2):95-102, 2014.

Renzulli, P.; Hostettler, A.; Schoepfer, A.M.; Gloor, B.; Candinas, D. Systematic review of atraumatic splenic rupture. Br. J. Surg., 96(10):1114-21, 2009.

Rogers, D.M.; Herrington, J.L. Jr.; Morton, C. Incidental splenectomy associated with Nissen fundoplication. Ann Surg., 191(2):153-6, 1980.

Shah, D.K. \& Zúñiga-Pflücker, J.C. An overview of the intrathymic intricacies of T cell development. J. Immunol., 192(9):401723, 2014.

Singla, S.; Keller, D.; Thirunavukarasu, P.; Tamandl, D.; Gupta, S.; Gaughan, J.; Dempsey, D. Splenic injury during colonoscopy--a complication that warrants urgent attention. J. Gastrointest. Surg., 16(6):1225-34, 2012.

Tan, K.; Lewis, G.R.; Chahal, R.; Browning, A.J.; Sundaram, S.K.; Weston, P.M. et al. Iatrogenic splenectomy during left nephrectomy: a single-institution experience of eight years. Urol. Int., 87(1):59-63. 2011.

Traub, A.; Giebink, G.S.; Smith, C.; Kuni, C.C.; Brekke, M.L.; Edlund, D.; Perry, J.F. Splenic reticuloendothelial function after splenectomy, spleen repair, and spleen autotransplantation. $N$. Engl. J. Med., 317(25):1559-64. 1987.

Urschel, J.D. Complications of antireflux surgery. Am. J. Surg., 166(1):68-70, 1993.

Yong, M.; Thomsen, R.W.; Schoonen, W.M.; Farkas, D.K.; Riis, A.; Fryzek, J.P.; Sørensen, H.T. Mortality risk in splenectomised patients: a Danish population-based cohort study. Eur. J. Intern. Med., 21(1):12-6, 2010.

Wang, Y.R.; Dempsey, D.T.; Richter, J.E. Trends and perioperative outcomes of inpatient antireflux surgery in the United States, 1993-2006. Dis. Esophagus., 24(4):215-23, 2011.
Wybran, J. Immunologic and hematologic sequelae of splenectomy. Acta Chir. Belg., 83:212-6, 1983.

Zhao, E.; Xu, H.; Wang, L.; Kryczek, I.; Wu, K.; Hu, Y. et al. Bone marrow and the control of immunity. Cell. Mol. Immunol., 9(1):11-9, 2012.

Zhao, Y.P.; Du, X.; Dai, M.H.; Zhang, T.P.; Liao, Q.; Guo, J.C. et al. Laparoscopic distal pancreatectomy with or without splenectomy: spleen-preservation does not increase morbidity. Hepatobiliary Pancreat Dis. Int., 11(5):536-41, 2012.

\section{Correspondence to:}

Prof. Dr. Carlos Manterola, Department of Surgery and CEMyQ

Universidad de La Frontera

Temuco

CHILE

E-mail: carlos.manterola@ufrontera.cl

Received: 16-05-2016

Accepted: 27-11-2015 